Bond University

Research Repository

\title{
A comparative study into legal education and graduate employability skills in law students through pro bono law clinics
}

Cantatore, Francina; McQuoid-Mason, David; Geldres, Valeska; Guajardo-Puga, Juan Carlos

Published in:

The Law Teacher

DOI:

10.1080/03069400.2020.1818464

Licence:

CC BY-NC-ND

Link to output in Bond University research repository.

Recommended citation(APA):

Cantatore, F., McQuoid-Mason, D., Geldres, V., \& Guajardo-Puga, J. C. (2021). A comparative study into legal education and graduate employability skills in law students through pro bono law clinics. The Law Teacher, 55(3), 314-336. https://doi.org/10.1080/03069400.2020.1818464

\section{General rights}

Copyright and moral rights for the publications made accessible in the public portal are retained by the authors and/or other copyright owners and it is a condition of accessing publications that users recognise and abide by the legal requirements associated with these rights.

For more information, or if you believe that this document breaches copyright, please contact the Bond University research repository coordinator 


\section{Promoting Innovation in Legal Education and Graduate Employability}

\section{Skills in Law Students through Pro Bono Law Clinics: A comparative}

study

Francina Cantatore ${ }^{\mathrm{a} *}$; David Mc Quoid-Mason ${ }^{\mathrm{b}}$; Valeska Geldres-Weiss ${ }^{\mathrm{c}}$; Juan

Carlos Guajardo-Puga ${ }^{\mathrm{d}}$

${ }^{a} B A$ LLB (Hons) MA PhD GDLP (Hons), Associate Professor of Law, Bond University, Australia; ${ }^{b} B$ Comm (Natal) LLB (Natal) LLM (London) PhD (Natal), Professor of Law, University of Kwazulu-Natal, South Africa; ${ }^{c}$ Professor and Dean of Business and Law, Universidad de La Frontera, Chile; ${ }^{d}$ Clinician and Lawyer, Universidad de La Frontera, Chile

*Corresponding author. Email: fcantato@bond.edu.au 


\begin{abstract}
Law students face challenges when entering the employment market irrespective of where they reside. Apart from increasing competition from their peers, there is often disconnect between the theory in law courses and the realities of legal practice. These challenges have been exacerbated by the COVID-19 pandemic which may affect graduate lawyers' job prospects and graduate skills expectations in the foreseeable future. The significant leap from "student" to "early career lawyer" or "graduate lawyer" requires law schools to be more proactive in incorporating practice-based legal skills. Whether gained through clinical education, external work experience or pro bono programmes, the effect of practical work experience is to increase self-confidence, practice knowledge, and consequently, employability in students. Extra-curricular community engagement has been widely recognised as enhancing graduate employability by combining experiential learning, coursework and community service. In this context, pro bono teaching clinics can provide suitable learning opportunities for law students. This paper focusses on the perceived benefits of experiential learning in pro bono teaching clinics with reference to three case studies of successful law teaching clinics within law faculties in different jurisdictions: an established law clinic in Australia; an established law clinic in South Africa; and an emerging law clinic in Chile. It also examines the impact of employment issues faced in diverse employment landscapes and how law students can increase their workplace readiness through a law clinic experience.
\end{abstract}

Key words: legal education; graduate employability; law clinics; pro bono; practice knowledge 


\section{INTRODUCTION}

Legal services employers and law firms are demanding more of law graduates when they enter practice, due to increased client expectations and rapid technological advances. ${ }^{1}$ This often means that graduates struggle to meet workplace demands, especially in a technology driven era. Law students face a number of challenges when entering the employment market, irrespective of where they reside. Apart from increasing competition from their peers, there is often disconnect between the theory they are taught in law courses and the realities of legal practice they are faced with when stepping into the "real world". The significant leap from "student" to "early career lawyer" or "graduate lawyer" requires law schools to be more proactive in incorporating practice-based legal skills. Whether gained through clinical education, external work experience or pro bono programmes, the effect of practical work experience is to increase self-confidence, practice knowledge, and consequently, employability in students.

It has been widely recognised that extra-curricular community engagement enhances graduate employability by combining experiential learning, coursework and community service. Law clinic experience generally exposes students to the realities of real client contact, real-life matters and interacting with their peers and supervising lawyers. In this context, pro bono teaching clinics can provide suitable learning opportunities for law students. This paper focusses on the benefits of experiential learning in a law clinic with reference to three case studies of successful law teaching clinics within university law faculties in different jurisdictions: an established law clinic in Australia; an established law clinic in South Africa; and an emerging law clinic in Chile. It also examines the impact of

\footnotetext{
${ }^{1}$ Francina Cantatore, 'New Frontiers in Clinical Legal Education: Harnessing Technology to Prepare Students for Practice and Facilitate Access to Justice' (2019) 5(1) Australian Journal of Clinical Education $<$ https://ajce.scholasticahq.com/section/1214-article>.
} 
employment issues faced in different jurisdictions and how law students can prepare themselves for the workplace through a law clinic experience.

\section{CLINICAL LEGAL EDUCATION AND PRO BONO CLINICS IN AUSTRALIAN, SOUTH AFRICAN AND CHILEAN LAW SCHOOLS}

Studies have shown that extra-curricular community engagement enhances graduate employability by combining experiential learning, coursework and community service. ${ }^{2}$ This is particularly evident in the experience gained by students in university law clinics, where students have access to practice-based learning opportunities. Clinical legal education (CLE) has long been recognised as a vehicle for facilitating interaction with 'real' clients and cases; development of social responsibility; fostering empathy and interpersonal skills; enabling networking and integration with legal professionals; and promotion of ethical behaviour in students. ${ }^{3}$ CLE is generally defined as a student's involvement with 'real clients' in a legal centre, ${ }^{4}$ in-house campus clinic, or through a placement programme or internship. ${ }^{5}$ In this context, the term refers to "any law school course or program in which law students participate in the representation of actual clients under the supervision of a lawyer/teacher". 6

\section{Australia}

In Australia, CLE has been incorporated in most law schools. A comprehensive review of law school clinics in Australia by Evans et al revealed that most Australian law

\footnotetext{
${ }^{2}$ Shelley Kinash and others, 'Supporting Graduate Employability from Generalist Disciplines Through Employer and Private Institution Collaboration' (Report, Australian Government Office for Learning and Teaching, 2015) 11.

${ }^{3}$ Francina Cantatore, 'Boosting Law Graduate Employability: Using a Pro Bono Teaching Clinic to Facilitate Experiential Learning in Commercial Law Subjects' (2015) 25(1) Legal Education Review 147.

${ }^{4}$ See e.g., Susan L Campbell, 'Blueprint for a Clinical Program' (1991) 9(2) Journal of Professional Legal Education 121, 122; Frank S Bloch, 'The Andragogical Basis of Clinical Legal Education' (1982) 35(2) Vanderbilt Law Review 321, 326.

${ }^{5}$ See e.g., Graeme Coss, 'Field Placement (Externship): A Valuable Application of Clinical Education' (1993) 4(1) Legal Education Review 29; cf Laura Lundy, 'The Assessment of Clinical Legal Education: An Illustration' (1995) 29(3) Law Teacher 311; Janet Motley, 'Self-Directed Learning and the Out-of-House Placement' (1989) 19(1) New Mexico Law Review 211.

${ }^{6}$ Bloch (n 4) 326.
} 
schools had implemented CLE programmes. ${ }^{7}$ The report distinguished between various models, namely: wholly law school funded in-house live-client clinics, in-house live-client clinics (with some external funding), external live-client clinics ('agency clinics'), externships (including internships and placements) and clinical components in other courses (including simulations of legal practice activities and encounters). ${ }^{8}$ Although the models vary, the focus of these clinics are invariably practice-based and skills orientated. Although there is some overlap, CLE and pro bono programmes have generally been regarded as "separate and distinct entities". ${ }^{9}$ The main distinguishing factors between the two models have been identified as follows:

a) Academic credit is usually awarded for CLE, ${ }^{10}$ as opposed to purely voluntary nonreward arrangements for pro bono students.

b) The term 'pro bono' refers to voluntary work done out of a sense of professional responsibility, where the primary motivation for the work is a concern for justice or for reasons of kinship or friendship, as opposed to securing gain. ${ }^{11}$

c) CLE programmes typically have a teaching focus whereas pro bono programmes typically have a community service focus. ${ }^{12}$

d) Usually pro bono programmes are at no financial cost to students whereas academic fees are usually payable for CLE.

\footnotetext{
${ }^{7}$ Adrian Evans and others, 'Best Practices Australian Clinical Legal Education' (Report, Australian Government Office for Learning and Teaching, 2012) 7; Kingsford Legal Centre, Clinical Legal Education Guide 2011-12 (Guide, University of New South Wales, 2007) <http://www.klc.unsw.edu.au/sites/klc.unsw /CLE_GUIDE_2011_12.pdf>; see also National Pro Bono Resource Centre, 'Pro Bono and Clinical Legal Education Programs in Australian Law Schools' (Information Paper, August 2004) $<$ http://www.nationalprobono.org.au/publications/documents/PUBLISHEDVERSION_000.doc $>$. 8 ibid 7.

${ }^{9}$ Les A McCrimmon, 'Mandating a Culture of Service: Pro Bono in the Law School Curriculum' (2003) 14(1) Legal Education Review 53, 54-57.

${ }^{10}$ Evans and others (n 7) 23.

${ }^{11}$ John Corker, 'How Does Pro Bono Students Australia (PBSA) Fit with Clinical Legal Education in Australia?' (Third International Journal of Clinical Legal Education Conference and Eighth Australian Clinical Legal Education Conference, 13-15 July 2005) 5.

12 ibid 6.
} 
e) CLE programmes generally require formal assessment procedures to produce specific learning and teaching outcomes whereas pro bono programmes often implement informal feedback and reflective practices.

Giddings argues that despite the similarities, a definite difference in objectives exists between the two. ${ }^{13}$ He suggests that while the "practice based context of clinical legal education has the potential to offer a very rich learning environment", ${ }^{14}$ these benefits can be lost in an environment without the necessary supervision or control over casework. ${ }^{15}$ In his article on pro bono work in law schools, Grimes also argues that 'professionally supervised' (by legal practitioners) student involvement in practical legal work at university will have a multitude of benefits. ${ }^{16}$ Thus, in both CLE and pro bono programmes there should be a requirement for professional supervision to maximise the benefits and increase the learning outcomes for student participants. ${ }^{17}$

The Australian law clinic case study in this research is a commercial law clinic which provides free legal advice to small businesses and not-for-profits on a pro bono basis.

\section{South Africa}

CLE in South Africa is well established and has been successfully implemented since $1971,{ }^{18}$ when the first South African law clinic run by law students was established at the University of Cape Town. ${ }^{19}$ By the International Legal Aid Conference held in Durban in July 1973, an off-campus law clinic had also been established at the University of the

\footnotetext{
13 Jeff Giddings, 'Contemplating the Future of Clinical Legal Education' (2008) 17(1) Griffith Law Review 1, 14.

14 ibid 17.

15 ibid.

${ }^{16}$ Richard Grimes, 'Why (and how to) do Pro Bono Work in Law Schools' (2008) 6(1) Journal of Commonwealth Law and Legal Education 27.

${ }^{17}$ Cantatore, 'Boosting Law Graduate Employability' (n 3) 153.

18 John Mubangizi and David McQuoid-Mason, 'The Role of University-based Law Clinics in Litigation, with Specific Reference to South Africa' (2013) 38(1) Journal for Juridical Science 47.

${ }^{19}$ David McQuoid-Mason, 'Methods of Teaching Civil Procedure' (1982) 7(2) Journal for Juridical Science 160 .
} 
Witwatersrand. Thereafter, in August 1973, a mobile law clinic was established at the University of KwaZulu-Natal (UKZN). ${ }^{20}$ Ten years later, most universities had established law clinics. ${ }^{21}$ Initially, during the apartheid era, law clinics provided pro bono services and the emphasis was on advice and assistance to poor and marginalised members of the community — the vast majority of whom were black victims of the apartheid system — rather than teaching skills, apart from the skills needed to provide such advice and assistance. ${ }^{22}$ This was in line with international trends at the time, when it was recognised internationally, for instance, that in Africa law students could play a valuable role in providing legal aid services:

Students represent a cheap source of manpower, which in the presence of proper supervision reaches a standard at least equal to that of a young qualified lawyer ...The well-supervised use of law students will significantly ease the limitations under which most of the legal aid programmes in Africa now have to work; it is only through student programmes that there is any possibility in the near future for legal services becoming widely available to the poor. ${ }^{23}$

It has been acknowledged that CLE is continuously evolving in South African university law clinics, and that "experimentation with clinical models and assessment regimes may ... [provide] valuable experiences for future progress." 24 For example, if law clinic students were to appear in court, clinics would need to ensure that students have proper lawyering skills and supervision by qualified practitioners so that legal aid clients are adequately represented. ${ }^{25}$

\footnotetext{
${ }^{20}$ McQuoid-Mason, 'Methods of Teaching Civil Procedure' (n 19).

${ }^{21}$ DJ McQuoid-Mason, 'The Role of Legal Aid Clinics in Assisting Victims of Crime' in Willem Johannes Schurink and others (eds), Victimisation: Nature and Trends (HSRC Press, 1992) 559. See also, Maisel P Clinical Legal Education in South Africa: Part 1 A Statistical Report (unpublished, 1999).

${ }^{22}$ See DJ McQuoid-Mason, An Outline of Legal Aid in South Africa (Butterworths, 1982) 153.

${ }^{23}$ F Reyntjens in FA Zemans (ed) Perspectives on Legal Aid (1979) 36.

${ }^{24}$ DF Chavkin, 'Matchmaker, Matchmaker: Student Collaboration in Clinical Programs' (1994) 1(2) Clinical Law Review 199.

25 The Supreme Court in the US recognised the use of properly supervised law students to fulfil the constitutional right to counsel many years ago. See Argersinger v Hamlyn S Ct 2006 (1979).
} 
As far back as 1985, McQuoid-Mason was requested by the then Liaison Committee of the former Association of South African Law Societies to draft student practice rules for South Africa. The rules were duly drafted, and unanimously adopted by the Liaison Committee which consisted of representatives from the legal profession and law faculties. However, even though they were favourably received by the then apartheid Minister of Justice, they were never introduced. After the fall of apartheid, the first Minister of Justice under the new democratically elected government agreed to introduce the rules, but never did so. ${ }^{26}$

CLE now forms part of the LLB curriculum at most South African universities. ${ }^{27}$ There are many similarities in the approach to CLE in South African law schools, but it has been noted that methods of implementation differ, particularly relating to student assessment. ${ }^{28} \mathrm{De}$ Klerk states that no law school in South Africa can claim to produce competent graduates without clinical experience, as "( $(\mathrm{t})$ here is no substitute for the real thing". ${ }^{29} \mathrm{He}$ is critical of curricula which only offer CLE as an elective, as some students will be allowed "to enter the practice of law without ever having seen a client, been inside a courtroom or interviewed a witness". These sentiments are echoed by many South African scholars and practitioners, ${ }^{30}$ considering that, "[t]he ability to handle facts ... must be developed in an environment in which the presentation of facts resembles that in the real world." 31

\footnotetext{
${ }^{26}$ David J McQuoid-Mason, 'The Delivery of Civil Legal Aid Services in South Africa' (2000) 24(Symposium) Fordham International Law Journal S111, S129.

${ }^{27}$ Margaret Martin Barry and others, 'Teaching Social Justice Lawyering: Systematically Including Community Legal Education in Law School Clinics' (2012) 18(2) Clinical Law Review 401-458.

${ }^{28}$ Mariette du Plessis, 'Clinical Legal Education Models: Recommended Assessment Regimes' (2015) 18(7) Potchefstroomse Elektroniese Regsblad $2778<\mathrm{http}$ //www.scielo.org.za/scielo.php?script=sci_serial\&pid= 1727-3781\&lng=en\&nrm=iso $>$.

${ }^{29}$ Willem De Klerk and others, Clinical Law in South Africa (LexisNexis, $2^{\text {nd }}$ ed, 2006), 246-250.

${ }^{30}$ See e.g., YAVawda, 'Learning from Experience: The Art and Science of Clinical Law' (2004) 29(1) Journal for Juridical Science 116, 124; S K Parmanand, 'Raising the Bar: A Note on Pupilage and Access to the Profession' (2003) 14(2) Stellenbosch Law Review 199, 202-4; McQuoid-Mason, 'Methods of Teaching Civil Procedure' (n 19) 162.

${ }^{31}$ McQuoid-Mason, 'Methods of Teaching Civil Procedure' (n 19) 162.
} 
The recently introduced Legal Practice Act (' $L P A ')^{32}$ in South Africa now requires all legal practitioners to undertake "community service" work on an annual basis. ${ }^{33}$ Such work includes assisting universities with practical legal training including supervision of law clinic students. ${ }^{34}$ The $L P A$ provides that the Minister of Justice and Constitutional Development must, after consultation with the Legal Practice Council, "prescribe the requirements for community service from a date to be determined by the Minister, and such requirements may include (a) community service as a component of practical vocational training by candidate legal practitioners; or (b) a minimum period of recurring community service by practising legal practitioners upon which continued enrolment as a legal practitioner is dependent". ${ }^{35}$ It has been pointed out that the reference to "community service" could be taken to include pro bono service. ${ }^{36}$ The matter will be finally settled when the Minister publishes the necessary directives or regulations.

\section{Chile}

Similarly, in Chile there is a strong recognition of the importance of pro bono legal services; however, these are provided primarily through government organisations such as the Chilean Pro Bono Foundation, Chile's leading clearinghouse for pro bono work. It is the only non-profit organisation that focusses on finding and distributing pro bono opportunities to private attorneys. ${ }^{37}$

\footnotetext{
${ }^{32}$ Legal Practice Act No. 28 of 2014 (SA) s 29.

33 The Legal Aid Council has a website with the names and addresses of pro bono lawyers in the different provinces $<$ https://lpc.org.za/members-of-the-public/> accessed on 17 May 2020. See also, ProBono.org $<$ http://www.probono.orgl> accessed on 17 May 2020.

${ }^{34}$ Legal Practice Act (n 32) s 29(2).

35 ibid s 29(1)

${ }^{36}$ Erica Emaden, 'More Clarity on Pro Bono under the Legal Practice Act' De Rebus (South Africa, 1 February 2017) 26.

${ }^{37} \mathrm{See}<\mathrm{http}: / /$ www.probono.cl $>$.
} 
Article 19 of the Chilean Constitution ${ }^{38}$ guarantees the right to a legal defence and the right to an attorney; stating that the law will provide defendants who cannot afford the services of an attorney the means to secure resources. In order to implement this basic constitutional principle, ${ }^{39}$ the Chilean Ministry of Justice proposed Corporations for Legal Assistance (CAJs), which were duly created by law and provides public, decentralized, and non-profit public services, and are responsible for providing free guidance and legal assistance to anyone in need with no financial means to obtain assistance on their own. ${ }^{40}$ The activities of the CAJs are, however, limited to the areas of civil, labour, family and old criminal system matters as well as providing legal assistance to the victims of crime. ${ }^{41}$

To obtain a license to practice law in Chile it is necessary to have a law degree from a Chilean university and to successfully complete a postgraduate-professional-practice period of six months in a CAJ before the professional title of lawyer is conferred by the Supreme Court. Notwithstanding that most of the CAJ legal services are provided by post graduate law students, their work is supervised by a staff of internal qualified lawyers directly employed by the CAJ. ${ }^{42}$

The Chilean Pro Bono Foundation states that it has become common practice for law schools to require its students to successfully complete at least one semester of work in their free legal clinics to obtain a law degree. ${ }^{43}$ There are different programmes involving universities, for example "Desafío pro bono" (the pro bono challenge), where students are

\footnotetext{
${ }^{38}$ Constitución Política De La República De Chile art 19 (3).

${ }^{39}$ Law Number 17,995, passed in 1981 by the Ministry of Justice.

${ }^{40}$ Sergio Díez, María Francisca Salas and Carolina Contreras, 'Pro Bono Practices and Opportunities in Chile' in Global Pro Bono Survey (Latham and Watkins LLP) $122<$ https://www.lw.com/admin/Upload/ Documents/Global\%20Pro\%20Bono\%20Survey/pro-bono-in-chile.pdf>.

${ }^{41}$ There are four CAJs: CAJ Tarapacá, CAJ Valparaíso, CAJ Metropolitana and CAJ Bío Bío. Each CAJ focusses its work in a different region of the country. A Social Work and Legal Assistance for the Family Foundation (Fundación de Asistencia Social y Legal de la Familia) also collaborates with CAJs in providing the services referred to above.

42 Díez, Salas and Contreras (n 40).

43 ibid 126.
} 
invited to propose ideas involving pro bono work. The best ideas are chosen, and the students whose idea or project is chosen wins the opportunity to be assisted by a specific law firm affiliated to the Foundation in order to develop their idea. In addition, the Chilean Pro Bono Foundation has partnerships with law schools of some universities. ${ }^{44}$

The pro bono clinic at the Universidad de La Frontera which is the focus of this study is unique in the sense that it has a commercial focus and provides legal advice and assistance to small businesses which face insolvency issues. It fills a gap in the types of pro bono services usually offered by law clinics and as such provides an innovative framework for future commercial law clinics in Chile.

It may be observed that CLE programmes in these diverse Australian, Chilean and South African jurisdictions are characterised by certain common features and similar stakeholders. For example, there are generally three stakeholder groups involved in these activities, namely law students, the community at large, and law professionals and/or law academics. The focus of CLE also appears to be consistent, i.e., a focus on legal skills education and some type of community service being offered. In many instances the students' and lawyers' involvement could be described as volunteer activities or pro bono services. It has been demonstrated that that pro bono activities need not exclude a strong learning and teaching focus, and that practical legal skills and ethics, as well as social responsibility, can be effectively taught within pro bono teaching clinics. ${ }^{45}$ Additionally, there has been a move towards recognising that law schools, and CLE programmes in particular, provide a suitable framework within which to introduce students to the increased demands of legal practice in the technology age. ${ }^{46}$

\footnotetext{
${ }^{44}$ See e.g., Universidad Católica de Chile; Universidad de Chile; Universidad Diego Portales; and Universidad Adolfo Ibáñez.

${ }^{45}$ Cantatore, 'Boosting Law Graduate Employability' (n 3) 149.

${ }^{46}$ Cantatore, 'New Frontiers in Clinical Legal Education' (n 1).
} 


\section{THE EMPLOYMENT LANDSCAPE FOR LAW GRADUATES}

\section{Australia}

In 2018, McDonald Murholme, managing director of Alan McDonald, issued a public response to PM Turnbull blaming universities for oversupply of law graduates, citing data from the Australian Financial Review (AFR) that revealed there had been over 15,000 law graduates each year in Australia whereas the legal profession only comprised of approximately 66,000 solicitors. ${ }^{47}$ However, a 2018 survey by the Council of Australian Law Deans of 39 law schools in Australia revealed the total number of Australian law graduates, either starting employment or entering the job market in 2018 was much less than that, 8,499 in total. ${ }^{48}$ Although lower than the past number cited by the AFR, it is still a significant number of law graduates in the context of the latest Australian law profession numbers recorded by the New South Wales Law Society in October 2018 of 76,303 practising solicitors. ${ }^{49}$ In general, unemployment rates of tertiary educated people who are without work but actively seeking employment (aged between 25-64) in Australia are 3.3\%. ${ }^{50}$

Also in 2018, it was reported that "[t]he majority of employers recruiting for solicitors attract a high number of qualified applicants and are able to fill their vacancies relatively easily." ${ }^{51}$ Employers considered qualified applicants unsuitable if they lacked the experience

\footnotetext{
${ }^{47}$ Emma Ryan, 'Frustration Grows over Unis 'Cashing In' on Law Grad Oversupply' Lawyers Weekly (online, 19 February 2018), <https://www.lawyersweekly.com.au/sme-law/22768-frustration-grows-over-unis-cashingin-on-law-grad-oversupply>; Law Council of Australia, 'How Many Lawyers Are There in Australia' (Law Council of Australia) <https://www.lawcouncil.asn.au/resources/faqs/how-many-lawyers-are-there-inaustralia>.

${ }^{48}$ Council of Australian Law Deans, '2018 Data Regarding Law School Graduate Numbers and Outcomes' (Factsheet, 2018) <https://cald.asn.au/wp-content/uploads/2019/07/Updated-FactsheetLaw_Students_in_Australia-20-04-2019.pdf $>$.

${ }^{49}$ NSW Law Society, '2018 National Profile of Solicitors' (Final Report, NSW Law Society) $<$ https://www.lawsociety.com.au/sites/default/files/2019-07/2018\%20National\%20Profile\%20of\%20 Solicitors.pdf $>$.

${ }^{50}$ Organisation for Economic Co-operation and Development [OECD], 'Unemployment Rates by Education Level' (Web Page) <https://data.oecd.org/unemp/unemployment-rates-by-education-level.htm\#indicator-chart>.

${ }^{51}$ Commonwealth, 'Department of Jobs and Small Business Report' (Report, March 2018),

$<$ https://www.employment.gov.au/annualreport2018>. The methodology underpinning this research is outlined at Department of Jobs and Small Business, 'Skill Shortage Research Methodology' (Document library, Australian Government).
} 
required for the role. Experience in the specific field of law (such as commercial or family law) related to the vacancy was a requirement for most employers. Other reasons for unsuitability included poor communication skills or organisational fit and a poor written application or interview performance. ${ }^{52}$ There is significant agreement on the broad categories of desirable graduate capabilities cited by institutions, employers and industry bodies, including what are often referred to as the 'generic' or 'soft' skills, such as communication skills, teamwork, critical thinking, problem-solving, self-management, digital literacy and global citizenship. ${ }^{53}$

The COVID-19 pandemic had a significant impact on graduate employment in 2020. For example, leading commercial law firm Gadens deferred its 2020 graduate programme as several firms delayed making 2021 offers as they struggled to balance the COVID-19 downturn with the long-term need to attract top talent from Australia's law schools. ${ }^{54}$ Both MinterEllison and Gilbert and Tolbin publicly announced cuts to partner spending and that they were asking staff to buy leave. ${ }^{55}$ MinterEllison also reduced partner drawings by half, put non-essential business projects on hold and freezes on new hires and deferred promotion to 2021. ClaytonUtz put a temporary freeze on hiring and offered staff the ability to purchase up to four weeks of leave between now and the end of financial year. ${ }^{56}$

Many other law firms were severely impacted and suffered a significant downturn in revenue as a result of the global coronavirus pandemic. ${ }^{57}$ Small and medium size firms were

\footnotetext{
${ }^{52}$ Commonwealth (n 51).

${ }^{53}$ Trina Jorre de St Jorre and Beverley Oliver, 'Want Students to Engage? Contextualise Graduate Learning Outcomes and Assess for Employability’ (2018) 37(1) Higher Education Research \& Development 45.

${ }^{54}$ Hannah Wootton, 'Graduate Programs Stall as Virus Hits Lawyers' Financial Review (online, 30 April 2020) $<$ https://www.afr.com/companies/professional-services/law-firms-grapple-with-graduate-hiring-amid-covid-19downturn-20200424-p54n3q>.

${ }^{55}$ Naomi Neilson, 'BigLaw Makes Cuts, Prepares for COVID-19 Impacts' Lawyers Weekly (online, 5 April $2020)<$ https://www.lawyersweekly.com.au/biglaw/27907-biglaw-makes-cuts-prepares-for-covid-19-impacts>. 56 ibid.

${ }^{57}$ See e.g., Jerome Doraisamy, 'International Firm Cuts Associates' Salary by 20\%, Adjusts Partner Profits' Lawyers Weekly (online, 3 May 2020) <https://www.lawyersweekly.com.au/biglaw/28178-international-firm-
} 
facing challenges in the form of balancing the need to ensure their staff remained safe and healthy, while also dealing with issues and concerns from clients who were affected by the virus. $^{58}$

The repercussions of the COVID-19 pandemic may reverberate in the legal profession not only in the short and medium term, but for years to come. This may result in increased expectations of graduate employability skills, e.g. in respect of information and communications technology (ICT) skills, problem solving skills and resilience.

\section{South Africa}

South Africa inherited the United Kingdom concept of a divided bar of solicitors and barristers, which in South Africa are referred to as attorneys and advocates. The $L P A^{59}$ was introduced in attempt to fuse the two branches of the legal profession in South Africa. In practice, however, although de jure the two branches are fused in terms of the Act, de facto the division of the profession has continued. While all prospective legal practitioners now have to obtain the same qualifications for the purposes of admission, they are free to join a bar association to practice as advocates, by satisfying the additional requirements for membership, such as undertaking a pupillage and writing a Bar Admission Examination. The National Bar Council of South Africa has been established as a voluntary association, although all practitioners (i.e., attorneys and advocates) are now governed by the Legal Practice Council. ${ }^{60}$

cuts-associates-salary-by-20-adjusts-partner-profits?utm_source=LawyersWeekly\&utm_campaign=04_05_2020 \&utm_medium=email\&utm_content $=1 \& u t m \_$emailID $=>$

${ }^{58}$ Tony Zhang, 'How SME Firms are Battling the Coronavirus' Lawyers Weekly (online, 19 March 2020)

$<$ https://www.lawyersweekly.com.au/sme-law/27765-how-sme-firms-are-battling-the-coronavirus >

${ }^{59}$ Legal Practice Act (n 32).

${ }^{60}$ ibid s 6. 
All law graduates in South Africa wishing to practice as lawyers have to undertake an internship and attend an approved practical training course. ${ }^{61}$ In the past, such courses have varied from five months full-time practical training schools to parttime five week short courses. It is not certain, however, if the short courses will be retained - it will depend on what the Legal Practice Council decides. ${ }^{62}$ In addition, the aspiring legal practitioners must pass a national admission examination. ${ }^{63}$

It is unavoidable that the employment landscape for law graduates is affected by the national economy, which is currently depressed in South Africa. ${ }^{64}$ The South African economy contracted by $1.4 \%$ in the fourth quarter of 2019 , following a contraction of $0.8 \%$ in the third quarter, the worst results since the 2008 global financial crisis. ${ }^{65}$ Unemployment rate of tertiary educated people who are without work but actively seeking employment (aged between 25-64) is 6.2\%. ${ }^{66}$ Comparatively, first year registrations at South African universities in 2018 for the LLB degree was 7,239 (or 9,268 if BA Law and BCOM Law is included).

Even under normal economic conditions, usually only about half of law graduates complete their articles if aspiring to become attorneys. The other half enter diverse fields such as commerce, insurance and the public service. ${ }^{67}$ As at January 2019, the total number of attorneys in South Africa was 27,223. ${ }^{68}$ Also, in 2019 the Council on Higher Education, the statutory body for quality assurance, made extensive recommendations for changes to the

\footnotetext{
61 ibid s 26.

${ }^{62}$ Legal Practice Act (n 32) s 27(1), which requires the Legal Practice Council to issue rules regarding the structure of the vocational training courses, but these have not yet been finalised.

63 ibid s 26.

${ }^{64} \mathrm{See}<\mathrm{http}: / /$ www.statssa.gov.za $>$.

65 ibid.

${ }^{66}$ OECD (n 50).

${ }^{67}$ Nomfundo Manyathi-Jele, 'Latest Statistics on the Legal Profession' De Rebus (South Africa, August 2015) 13.

${ }^{68}$ Law Society of South Africa, 'Statistics for the Attorneys' Profession' (Web Page, 2019)

$<$ https://www.lssa.org.za/about-us/about-the-attorneys-profession/statistics-for-the-attorneys-profession/>.
} 
LLB in South Africa, following repeated concerns by professional lawyers that law graduates were of poor quality. One of the recommendations was that there be a major cut to the number of students accepted into LLB courses. ${ }^{69}$

The compulsory internship requirement in South Africa was expanded to allow law graduates to complete articles at law clinics, Legal Aid South Africa (Legal Aid SA) and public interest law firms. ${ }^{70}$ Through its Candidate Legal Practitioner Recruitment Programme (approximately 600 Candidate Legal Practitioners are recruited at any given time), Legal Aid SA provides an invaluable gateway to the legal profession and has made a significant contribution to the transformation of the profession. ${ }^{71}$

Pursuant to the Attorneys Act of 1979, law graduates had to complete a one-year internship if they attended the full-time six month Law Society School for Legal Practice, or a two year internship if they attend the three and six week 'sandwich' Law Society Practical Training courses. Up until now, those wishing to become advocates under the Admission of Advocates Act of 1964 could be admitted immediately on graduation, but if they wished to join one of the Bars they had to complete a one year pupillage and write a Bar Examination. However, while much of this system remains intact, the $L P A$ has diluted the distinction between attorneys and advocates.

Law firms generally expect that students have a good knowledge of the law as well as research and drafting skills. Some of these skills are further developed in Legal Practice and Practical Training Courses. However, when recruiting students for articles of clerkship law

\footnotetext{
${ }^{69}$ Bongani Nkosi, 'Major Shake-up for Law Degree Following Report' IOL (online, 3 June 2019) $<$ https://www.iol.co.za/news/south-africa/major-shake-up-for-law-degree-following-report-24834116>.

70 Attorneys Amendment Act 115 of 1993 (SA) s 2.

${ }^{71} \mathrm{See}<$ https://legal-aid.co.za/working-at-legal-aid-south-africa/ $>$.
} 
firms tend to favour students who have completed clinical law courses as they expect that students would have gained some practical skills. ${ }^{72}$

In practice, law graduates who undertake articles often face the challenge that their principals may not adhere to the terms of their contracts and they may find themselves running errands for senior partners, doing menial tasks like photocopying etc., or being confined to departments such as those dealing with collections. In particular, law graduates from disadvantaged backgrounds have found it difficult to find articles, and to achieve success in the larger 'elite' firms. ${ }^{73}$ As in other jurisdictions, such as Australia, law graduates who wish to become advocates (barristers) face the challenge of establishing themselves as they do not have the luxury of colleagues in a law firm to sustain them.

Depending on the type of clinic, law clinics teach practical legal skills using interactive, reflective and experiential paradigm within a social justice context. ${ }^{74}$ Students learn interviewing, counselling, research, drafting, problem-solving, fact determination and communication skills, as well as sensitivity to and awareness of the problems that are experienced in poor and marginalized communities. ${ }^{75}$

Following the COVID-19 outbreak it was predicted that South Africa faced "a 12 to 24-month gradual recovery with the added complexity of managing a rebuild and growth plan spanning an initial period of at least six to eight years." 76 This economic fall-out would affect

\footnotetext{
${ }^{72}$ Werksmans Attorneys, 'So You Want to Be a Lawyer?' (2016) <https://www.up.ac.za/media/shared/10/ZP Files/without-prejudice-october-2016-so-you-want-to-be-a-lawyer-feature.zp102144.pdf>.

${ }_{73}$ Lisa R Pruitt, 'No Black Names on the Letterhead? Efficient Discrimination and the South African Legal Profession’ (2002) 23(3) Michigan Journal of International Law $545<$ https://repository.law.umich.edu/ $\mathrm{mjil} / \mathrm{vol} 23 / \mathrm{iss} 3 / 2>$.

${ }^{74}$ David Holness, 'Improving Access to Justice Through Compulsory Student Work at University Law Clinics' (2013) 16(4) Potchefstroomse Elektroniese Regsblad $328<\mathrm{http}: / /$ www.scielo.org.za/scielo.php?script=sci arttext\&pid=S1727-37812013000400009>.

$\overline{75}$ ibid. While there are pressures to join commercial practice in law firms, clinical experience can also result in students being committed to pro bono and public interest law work.

${ }^{76}$ BusinessTech, 'What South Africa's Economic Recovery Could Look Like', Business Tech (online, 3 May $2020)<$ https://businesstech.co.za/news/business/393442/what-south-africas-economic-recovery-could-looklike/>.
} 
the employment of law graduates for the foreseeable future, with law firm partners taking pay cuts of 50 per cent or more in order to keep their existing workforce intact during the COVID-19 crisis. $^{77}$

\section{Chile}

Chile has been one of Latin America's fastest-growing economies in recent decades, enabling the country to significantly reduce poverty. However, more than $30 \%$ of the population is economically vulnerable and income inequality remains high. ${ }^{78}$ In the context of social unrest, GDP growth decreased from 3.9 percent in 2018 to 1.1 percent in $2019 .{ }^{79}$ The unemployment rate in Chile was $7.22 \%$ in 2018 , a $0.27 \%$ increase from $2017 .{ }^{80}$ The unemployment rate of tertiary educated people who are without work but actively seeking employment (aged between 25-64) is 5.6\%. ${ }^{81}$

As previously noted, there is a mandatory professional practice period of 6 months at a CAJ in order to obtain a license to practise law in Chile. This often serves as the "second exposure to direct legal services, as many law schools incorporate clinical work as either a mandatory component of a law degree or a voluntary activity open to all students". ${ }^{82}$ This affords students the opportunity of developing business contacts with a view to obtaining

\footnotetext{
${ }^{77}$ Michael Pelly, 'COVID-19 Pain Kicks in for Law Firm Partners' Financial Review (online, 3 April 2020), $<$ https://www.afr.com/companies/professional-services/covid-19-pain-kicks-in-for-law-firm-partners-20200402p54g82>.

78 'The World Bank in Chile' (Web Page, 16 April 2020)

$<$ https://www.worldbank.org/en/country/chile/overview>.

${ }^{79}$ ibid.

${ }^{80}$ See 'Chile Unemployment Rate 1991-2020' (Web Page, 2020)

$<$ https://www.macrotrends.net/countries/CHL/chile/unemployment-rate>.

${ }^{81}$ OECD (n 50).

${ }^{82}$ Latham and Watkins LLP, 'Pro Bono Practices and Opportunities in Chile' (Memorandum, September 2015), $122-3<$ https://www.lw.com/admin/Upload/Documents/Global\%20Pro\%20Bono\%20Survey/pro-bono-inchile.pdf $>$.
} 
future employment. In addition, international student mobility related to study programmes or internships is encouraged to increase graduate employability. ${ }^{83}$

However, it has been alleged that in Chile social class imposes a heavy burden on outsiders and grants important advantages to insiders. In a study conducted by Ann McGinley in $2018,{ }^{84}$ she posited that many interviewees believed that class may be even more important than gender in hiring lawyers, especially for jobs at the prestigious law firms in Santiago. ${ }^{85}$ Some interviewees stated that important law firms hired "mediocre, young male lawyers from prominent families", but that women who are hired had to be exceptional. ${ }^{86}$ She also noted that women represented the majority of law students and there were considerable advances being made by female lawyers and judges; however, female lawyers still represented a small number of partners in most law firms. ${ }^{87}$

A 2015 Chilean report noted that approximately 3,384 lawyers were admitted before the Supreme Court in 2014, which was $16 \%$ more than $2013 .{ }^{88}$ The Colegio de Abogados de Chile, Chile's voluntary bar association, estimates that the 9000 members it has is only about $50 \%$ of licensed lawyers in Chile, ${ }^{89}$ indicating that there are approximately 18,000 practising lawyers in Chile.

\footnotetext{
${ }^{83}$ Valeska V Geldres, Martinho I Ribeiro de Almeida and Alenka Flander, 'Movilidad Internacional de Estudiantes Yempleabilidad: La Visión de los Empleadores' (2015) 10(30) Revista Iberoamericana de Ciencia, Tecnología y Sociedad $113<$ http://www.redalyc.org/articulo.oa?id=92441742004>.

${ }^{84}$ Ann C McGinley, 'Gender, Law, and Culture in the Legal Workplace: A Chilean Case Study' (2018) 60(3) Arizona Law Review 675 <https://scholars.law.unlv.edu/cgi/viewcontent.cgi?article=2171\&context=facpub>. ${ }^{85}$ McGinley ( $\mathrm{n} 84$ ) 739. She stated that the private school one attends is an issue in hiring by prestigious law firms, but not for judicial positions. Interview CH25, at 14. See also, Yves Dezalay and Bryant G Garth, 'The Internationalization of Palace Wars: Lawyers, Economists and the Contest to Transform Latin American States' (University of Chicago Press, 2002) 18, 21-2: The traditional firm was an institution of a family, and the lawyers were "gentlemen" who came from the upper class.

${ }^{86}$ McGinley (n 84) 706.

87 ibid 679.

${ }^{88}$ Latham and Watkins LLP (n 82) 123.

${ }^{89}$ International Coordinator, 'How to Practise in Chile' The Law Society (Web Page)

$<$ https://communities.lawsociety.org.uk/americas-and-caribbean/how-to-practise-in-chile/5044600.article>
} 
In general, Chileans benefit significantly from a tertiary education. In 2017, 84\% of tertiary-educated adults were employed in Chile. ${ }^{90}$ However, Organisation for Economic Cooperation and Development (OECD) statistics confirm that women with a tertiary education degree earn only $68 \%$ of the earnings of their male counterparts, 7 percentage points below the OECD average. ${ }^{91}$

The COVID-19 pandemic has also affected the Chilean economy. According to a survey conducted in Chile among company executives and directors, around $80 \%$ of respondents expected the country's economy to be bad or very bad six months after the outbreak in March 2020. Small and medium-sized companies were believed to have the worst prospects, as $91 \%$ of businesspeople surveyed thought their economic situation would worsen after the COVID-19 crisis. ${ }^{92}$ This would include law firms and could have a negative impact on the future employment of law graduates in the short to medium term.

\section{THE CASE STUDIES}

\section{Methodology and Research Instrument}

A previous pilot study has been undertaken in Australia with a group of law students pre- and post- clinical experience in a law clinic, based on a survey utilising the Graduate Employability Indicators ('GEI'), set out by Oliver et al for an Australian Learning and Teaching Council Report. ${ }^{93}$ This previous study's empirical research findings, derived from the Graduate Employability Survey ('the survey'), ${ }^{94}$ considered how students may benefit

\footnotetext{
${ }^{90}$ OECD, 'Education at a Glance 2019' (Country Note, 2019) <https://www.oecd.org/education/education-at-aglance/EAG2019_CN_CHL.pdf>.

91 ibid.

${ }^{92}$ See 'Expected Economic Situation Six Months after the Coronavirus Outbreak in Chile of March 2020'

Statista $(2020)<\mathrm{https}: / /$ www.statista.com/statistics/1108025/chile-economic-expectations/>.

${ }^{93}$ Beverley Oliver and others, Introducing the Graduate Employability Indicators (Report, Australian Learning and Teaching Council, 2011) <http://www.assuringgraduatecapabilities.com/uploads/4/5/0/5/45053363/ introducingthegei.pdf $\mathrm{s}$.

94 ibid.
} 
from involvement in pro bono law clinics in the context of work readiness. ${ }^{95}$ It found that there was an average increase of $13 \%$ in perceptions of competency in students after attending a semester long law clinic, as opposed to a control group which showed only a minimal increase of $2.7 \%$ in competence. ${ }^{96}$

i. $\quad$ The Survey

The GEI in the survey are listed in Table 1 below.

Table 1: GEI Survey Content

\begin{tabular}{|l|l|}
\hline Abbreviated title & Full text in the GEI \\
\hline 1. Knowledge & Work related knowledge and skills \\
\hline 2. Writing & Writing clearly and effectively \\
\hline 3. Speaking & Speaking clearly and effectively \\
\hline 4. Thinking & Thinking critically and analytically \\
\hline 5. Quantitative & Analysing quantitative problems \\
\hline 6. Using ICT & $\begin{array}{l}\text { Using computing and information } \\
\text { technology }\end{array}$ \\
\hline 7. Teamwork & Working effectively with others \\
\hline 8. Independent Learning & Learning effectively on your own \\
\hline 9. Intercultural Understanding & Understanding people of other racial and \\
& ethnic backgrounds \\
\hline
\end{tabular}

${ }^{95}$ Francina Cantatore, 'The Impact of Pro Bono Law Clinics on Employability and Work-readiness in Law Students' (2018) 25(1) International Journal of Clinical Legal Education 147.

96 ibid 168. 


\begin{tabular}{|l|l|}
\hline 11. Values \& Ethics & $\begin{array}{l}\text { Developing a personal code of values and } \\
\text { ethics }\end{array}$ \\
\hline 12. Community Engagement & $\begin{array}{l}\text { Contributing to the welfare of your } \\
\text { community }\end{array}$ \\
\hline 13. Industry awareness & Developing general industry awareness \\
\hline 14. Social contexts & Understanding different social contexts \\
\hline
\end{tabular}

In the present research study, the same survey is utilised to compare the findings in law schools in three different jurisdictions, namely Australia, Chile and South Africa, and to observe the distinguishing factors that characterise different regions with regard to graduate employability. A widely-accepted definition of "graduate employability" is the achievement of "the skills, understandings and personal attributes that make an individual more likely to secure employment and be successful in their chosen occupations to the benefit of themselves, the workforce, the community and the economy". ${ }^{97}$

As in the pilot project ('the Report'), the research project underlying this article was conducted within the theoretic grounding of the GEI. The Report relied on seven clusters of attributes identified by universities, including: written and oral communication; critical and analytical (and sometimes creative and reflective) thinking; problem-solving (including generating ideas and innovative solutions); information literacy, often associated with technology; learning and working independently; learning and working collaboratively; and ethical and inclusive engagement with communities, cultures and nations. ${ }^{98}$

\footnotetext{
${ }^{97}$ Mantze Yorke, 'Employability in Higher Education: What It Is - What It Is Not' (Learning and Employability Series I, Higher Education Academy, April 2006) <http://www.employability.ed.ac.uk /documents/Staff/HEA-Employability_in_HE(Is,IsNot).pdf>.

${ }^{98}$ Cantatore, 'The Impact of Pro Bono Law Clinics' (n 95) 155.
} 
Based on these attributes, the survey included in the Report allows for the systematic collection of evidence of stakeholders' views of graduate achievement of employability skills. ${ }^{99}$ It has been acknowledged that the survey expands the list of attributes, mentioned above, further, by focussing on fourteen attributes, skills and personal qualities drawn from a number of related surveys. ${ }^{100}$ In this way the GEI can be used to determine the effectiveness of courses in preparing students for the workplace, by administering a survey to various stakeholder groups.

In this study, the GEI survey has been applied in the context of law students at three universities in different regions attending a law clinic over the course of a semester, by measuring their perception of competency against each other. In the survey students were instructed to indicate their level of competence in respect of each of the fourteen attributes, rated from $0-100 .{ }^{101}$ A copy of the GEI survey is attached as Annexure A.

\section{ii. $\quad$ Methodology}

This study involved the collection of both quantitative and qualitative data, from the survey as well as additional qualitative comments by students. In conducting this research, the established model proposed by the GEI (above) was used to survey the law clinic student stakeholder groups (Groups 1, 2 and 3) over the course of a full semester in 2019 and compare the results of the surveys from the three jurisdictions. Surveys were distributed to clinic students at the beginning and end of semester by an administrator who collected and stored the surveys securely. Student identification numbers or names were obtained in order to enable collation of the second (post-semester) survey data with the initial survey (pre-

\footnotetext{
99 ibid.

${ }^{100}$ George D Kuh, The National Survey of Student Engagement: Conceptual Framework and Overview of Psychometric Properties (Bloomington, Indiana University Centre for Postsecondary Research and Planning, 2004); Hamish Coates, 'Engaging Students for Success: Australasian Student Engagement Report' (Report, Australian Council for Educational Research, 2009).

101 Oliver and others (n 93).
} 
semester). Participant students of all groups were enrolled in a comparable law degree (LLB or JD). Group 1 consisted of Australian law students attending a law clinic. Similarly, Group 2 consisted of South African law students attending a law clinic and Group 3 consisted of Chilean law students attending a law clinic. The group numbers varied between groups, resulting in 27 participants in total. In addition, qualitative data was collected from participating students by way of online survey to provide further insight into their law clinic experience and perceived employability skills enhancement through their experience. Table 2 below sets out the student groups involved in the study.

Table 2: Student Groups surveyed

\begin{tabular}{|l|r|}
\hline Student Group & Participants \\
\hline 1. Australia: Bond University Law Clinic & 10 \\
\hline $\begin{array}{l}\text { 2. South Africa: University of Kwazulu- } \\
\text { Natal Law Clinic }\end{array}$ & 11 \\
\hline $\begin{array}{l}\text { 3. Chile: Universidad de La Frontera Law } \\
\text { Clinic }\end{array}$ & 6 \\
\hline Total number of law students & 27 \\
\hline
\end{tabular}

\section{Results and General Findings of the Research Study}

It should be noted that the findings and observations made here are based on the students' perceptions of their increase in the various skills. Students may have different perceptions of their original skill levels and therefore experience varied benefits from their clinic experiences. Thus, the average percentages of students' reported skills increases are employed in this discussion.

\section{Bond University, Australia}

Survey results 
Overall, the ten law clinic students reported an average increase of $22 \%$ in their graduate skills from beginning to end of semester. The most significant perceived increase in competency of $44 \%$ occurred in the areas of Knowledge and Industry Awareness. The lowest increased averages were in Teamwork (11\%) and Intercultural Understanding (12\%).

Students reported that Thinking, Quantitative skills and Values \& Ethics both increased around 13-15\%. Skills such as Speaking, ICT, Independent Learning and Social skills all increased around 19-21\%, whilst Writing skills, Problem Solving and Community Engagement improved by $25-26 \%$.

\section{Qualitative feedback}

In terms of motivation, $100 \%$ of participants agreed that they chose to volunteer at the clinic in order to gain practical experience, and 50\% stated that this aspect was the most enjoyable part of the clinic, while 50\% enjoyed the experience of dealing with clients most. Only $50 \%$ were motivated by a desire to help others. The most recognised benefit by $75 \%$ of respondents was a "better understanding of legal practice". Examples of student comments were:

- "I gained a working knowledge of how a firm would operate. I also have a better understanding of the technical aspects of a clinic and how much work goes into it to keep running." 102

- "I learned that a good file note is invaluable and how to alter my note taking style to better produce a better file note." 103

- "I have learnt client interview skills, drafting skills, and researching skills."104

\footnotetext{
102 Student comment (Survey, August 2019).

${ }^{103}$ Student comment, (Survey, August 2019).

${ }^{104}$ Student comment, (Survey, August 2019).
} 
- "I am much more confident and I have developed a more accurate understanding of what practice may be like."105

The following main aspects of the Australian law clinic experience were specifically commented on by students, as set out in Table 3 below:

\section{Table 3: Bond University Emerging Themes}

\begin{tabular}{|l|r|}
\hline Theme & \multicolumn{2}{|l|}{$\begin{array}{l}\text { Number of positive } \\
\text { comments }\end{array}$} \\
\hline Exposure to real work & 5 \\
\hline Exposure to lawyers & 2 \\
\hline Learning opportunity & 5 \\
\hline Application of practical skills & 3 \\
\hline $\begin{array}{l}\text { Gain insight into realities of } \\
\text { legal practice }\end{array}$ & \\
\hline
\end{tabular}

The comments and repetition of certain aspects of the law clinics demonstrate a predominant emphasis by participants on the ability to obtain practical experience, and an appreciation for developing practice-based skills. Their comments support the findings of the survey, which shows a perceived increase of over $43 \%$ in knowledge and industry awareness.

\section{University of KwaZulu-Natal, South Africa}

Survey results

${ }^{105}$ Student comment, (Survey, August 2019). 
The eleven law clinic students in this programme reported an average increase of $30 \%$ in their graduate skills from beginning to end of semester. ${ }^{106}$ The most significant perceived increase in competency was in the area of Community Engagement (52\%), followed by Industry Awareness (48\%) and Teamwork (46\%). The lowest increased averages were in Thinking (16\%), Problem Solving and Values \& Ethics (both 19\%). Students reported increases in the areas of Knowledge, Writing, Quantitative skills, Independent Learning, Intercultural Understanding and Social skills between 20-28\%. Speaking and ICT skills showed perceived increases of between $30-37 \%$.

\section{Qualitative feedback}

Some of the comments by students on the impact of the clinic were:

- "I gained confidence for consultations and obtained a better understanding of how to consult and to answer questions on official forms and from clients." 107

- "I benefitted from exposure to real world clients, indigenous issues and the legal aid process and learning practical legal skills like research, writing and client interviewing." 108

- "I benefitted by becoming a more critical thinker, a more confident speaker, with a better ability to research and understand law and a better understanding of people in our society." 109

- "I benefitted from practical experience interacting with real-life clients and experiences." 110

\footnotetext{
${ }^{106}$ The authors are indebted to Dave Holness and Janine Hicks of the Law School at the University of KwaZuluNatal, for conducting the surveys with their students in the two CLE courses they run.

${ }^{107}$ Student comment (Survey, November 2019).

${ }^{108}$ Student comment (Survey, November 2019).

${ }^{109}$ Student comment (Survey, November 2019).

${ }^{110}$ Student comment, (Survey, November 2019).
} 
The following main themes emerged from student comments as set out in Table 4 below:

\section{Table 4: University of KwaZulu-Natal Emerging Themes}

\begin{tabular}{|l|r|}
\hline Theme & $\begin{array}{l}\text { Number of positive } \\
\text { comments }\end{array}$ \\
\hline $\begin{array}{l}\text { Better understanding of legal } \\
\text { practice }\end{array}$ & 3 \\
\hline Learned/Improved practical skills & 7 \\
\hline Gained experience & 1 \\
\hline More confident & \\
\hline
\end{tabular}

\section{Universidad de La Frontera, Chile}

\section{Survey results}

The six law clinic students reported an average increase of $71 \%$ in their graduate skills from beginning to end of semester. The most significant perceived increases in competency were in the areas of Writing, Thinking, Quantitative and Problem Solving, which all showed an increase of over 100\%, the highest being Thinking (116\%). By far the lowest increased average was in Values \& Ethics (14\%), followed by ICT and Social skills (between $22-23 \%$ ). Students reported that skills such as Speaking, Teamwork, Independent Learning, Intercultural Understanding, Industry Awareness and Community Engagement improved between $54-78 \%$, whilst Knowledge increased by $91 \%$. The increases overall show a significant perception of increased employability skills over the reporting period.

\section{Qualitative feedback}

When questioned at the end of the clinic about any perceived benefits gained through their clinic experience, the following main themes emerged as set out in Table 4 below: 


\section{Table 5: Universidad de La Frontera Emerging Themes}

\begin{tabular}{|l|l|}
\hline Theme & $\begin{array}{l}\text { Number of positive } \\
\text { comments }\end{array}$ \\
\hline $\begin{array}{l}\text { Better understanding of legal } \\
\text { practice }\end{array}$ & 5 \\
\hline Exposure to lawyers & 6 \\
\hline Learned/Improved practical skills & 5 \\
\hline Gained experience & \\
\hline
\end{tabular}

Examples of specific comments by students were:

- "Throughout this experience I managed to improve my skills, have a real approach to the practice of the profession and how to manage the relationship with users."111

- "Personally, my experience with the Clinic has been very enriching since it has been a fundamental learning for my professional future, knowing certain functions in civil courts, since they have certain acts that are their own, including schedules. Not to mention the opportunity to litigate electronically, to know platforms and how to recognize certain judicial resolutions, which seen in practice, are much more theoretically understandable." 112

- "The greatest aspect of learning has been the possibility of actively participating in audiences and legal proceedings concerning two of the major problems of consumer relations in our country. The consumer right itself and, mainly, the insolvency law. On the other hand, one of the greatest lessons that the Legal Clinic has given me has been, for the future professional, the management of the virtual judicial office. 
Finally, the instance generated in these months in the Clinic has helped me to strengthen teamwork, the expression of ideas and arguments, as well as knowing first person to liquidators, judges, lawyers and, in general, the professionals involved in the exercise of insolvency right." 113

- "During my work within the UFRO Legal Clinic, I have been able to acquire a broad development of organizational skills in teamwork, together with greater knowledge of both theoretical and practical aspects of the legal issues addressed." 114

These observations by students show an appreciation for the practical knowledge acquired through the clinic experience, as well as concurrent benefits such as increased knowledge and the opportunity to assist consumers.

\section{Discussion and Comparative Findings}

\section{i. Survey}

All three groups reported significant increases in their graduate skills post-clinic experience. However, the averages varied considerably, with students in Chile reporting an average increased in skills of $71 \%$, more than three times the Australian average of $22 \%$. South African students reported a perceived increase in skills of $30 \%$, also higher than the Australian average. A detailed representation of the comparative research findings on increased graduate skills in the three universities is depicted in the bar chart below:

113 Student comment (Survey, August 2019).

${ }^{114}$ Student comment (Survey, August 2019). 
Figure 1: Comparison of Increase in Graduate Skills: Australia, South Africa and Chile

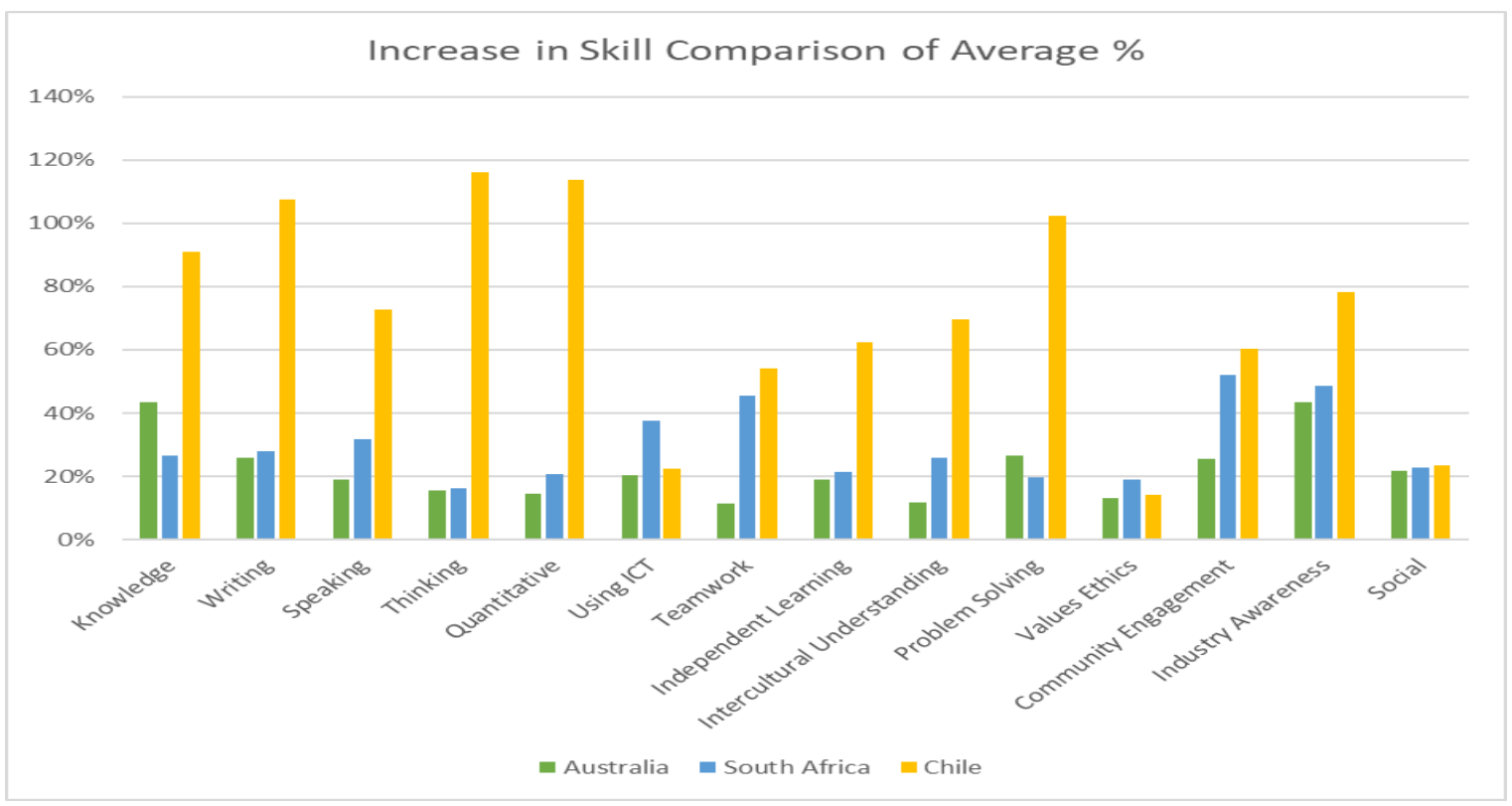

The most notable discrepancies in graduate skills increases between the groups occurred in the areas of Thinking and Quantitative skills, where Chilean students reported increases of $116 \%$ and $114 \%$ respectively, markedly higher than the other two jurisdictions. In comparison, Australian and South African groups both observed a mere $16 \%$ increase in Thinking, and a 14\% and 21\% increase in Quantitative skills, respectively. It may reflect a stronger focus in the Chilean clinic on these skills due to the particular clinic experience (mainly insolvency law); however, it may also be argued that students in Australia and South Africa perceived themselves as having higher levels of these skills to start with, and therefore reported a lower increase in these skills.

Chile showed the highest perceived increase of the three groups in all but two skills, namely Using ICT and Values \& Ethics, where South African students reported the highest average increases of $37 \%$ and $19 \%$ respectively. South African students regarded themselves as significantly more improved in Using ICT than the other two groups, with Australia reporting a $20 \%$ and Chile a $23 \%$ increase. 
An area where Australian students reported a significantly lower average increase than the other jurisdictions was in Teamwork, where they scored $11 \%$ as opposed to $46 \%$ in South Africa and 54\% in Chile. This result reflects a lesser emphasis on group work and more personal responsibility in the Australian clinic.

The area where student skills improvement was the most closely aligned was Social skills, which only showed a divergence of $1 \%$ for the three groups at $22 \%$ (Australia), $23 \%$ (South Africa) and 24\% (Chile). This result indicates that students of all three groups experienced a similar benefit of increased social skills in the law clinics.

The highest average improvement of the three groups was in the area of Industry Awareness (57\%) and the lowest average increase was in Values \& Ethics (16\%). This result is borne out by the student comments above which show a strong appreciation for the practical and industry experience gained in the clinics.

The survey results overall indicate that Chilean students found the clinic experience safe for the areas of Using ICT and Values \& Ethics - the most beneficial out of the three groups in terms of increasing their graduate employability skills, with a total average increase of $71 \%$. They especially benefitted from a marked increase in Thinking, Quantitative skills, Writing and Problem Solving, all of which increased by more than $100 \%$. Of all areas they benefitted the least from Using ICT; however, they still reported an average increase of 23\% in that skill.

Australian students perceived the lowest average increase in their employability skills $(22 \%)$ in comparison to the other two groups. By far the highest increases related to Knowledge and Industry Awareness (44\%), the lowest being Teamwork (11\%). Interestingly, however, the results of this survey reflect a perception of greater increased skills than the 
prior pilot survey undertaken at a law clinic at Bond University in 2016, ${ }^{115}$ which reported a total average increase in skills of $13 \%$. Thus, even though the Australian average increase is comparatively low when considered against the other two groups in this study, the Australian results are consistent with, and even improved from, the previous Australian survey in 2016 with a comparable group. It is also noteworthy that the control group of non-clinic students in that study only showed an increase of $2.7 \%$ in comparison. ${ }^{116}$

South African students sat somewhere between the Chilean and Australian groups, showing an average skills increase of 30\%. Their acquisition of skills appeared to be fairly evenly spread, the lowest being Thinking at $16 \%$ and the highest, Community Engagement, at $52 \%$. They benefitted the most from an increase in ICT skills (37\%) as opposed to Chilean students who rated that as the lowest increase. This may relate to the type of clinic experience in the respective clinics and the use of ICT during the clinic experience; alternatively it may indicate that South African students found exposure to ICT to be more beneficial than their Australian and Chilean counterparts.

\section{ii. Qualitative comments}

By and large, the students in all three groups had similar comments about the nature and benefit of their experience. A few distinct main themes emerged from the student experience, namely: a better understanding of legal practice; exposure to lawyers; improvement in practical skills; more confidence; and gaining experience. Incidence of recurring comments by the students on improvement in these skills areas were captured in Table 6 below:

Table 6: Emerging Themes: Student perceptions of increased skills/knowledge by theme

${ }^{115}$ Cantatore, 'Boosting Law Graduate Employability’ (n 3) 160.

116 ibid. 


\begin{tabular}{|l|r|r|r|r|}
\hline \multirow{2}{*}{$\begin{array}{l}\text { Comments regarding } \\
\text { the clinic experience }\end{array}$} & \multicolumn{5}{|c|}{ Number of occurrences } \\
\cline { 2 - 6 } & Australia & \multicolumn{1}{|c|}{ South Africa } & Chile & Totals \\
\hline $\begin{array}{l}\text { Better understanding } \\
\text { of legal practice }\end{array}$ & 6 & 3 & 5 & 14 \\
\hline Exposure to lawyers & 3 & & 2 & 18 \\
\hline Learned/Improved & 5 & & 6 & 2 \\
practical skills & 1 & 1 & & 14 \\
\hline More confident & 3 & 6 & 5 & \\
\hline Gained experience & & & & 5 \\
\hline
\end{tabular}

Evidently the highest perceived benefits by all three groups were related to practical legal experience and skills as demonstrated by three of the five emerging themes.

Additionally, 'exposure to lawyers' indicates the appreciation of some students from Australia and Chile for the opportunity to build relationships with members of the profession. This was not prevalent among South African students who mainly undertake their clinical experience the University of KwaZulu-Natal law clinic, which employs three full time inhouse lawyers who supervise them when conducting interviews and giving legal advice, so there is little opportunity to interact with lawyers outside the clinic. ${ }^{117}$ Gaining confidence was perceived as an associated benefit experienced by single Australian and South African clinic students.

A closer examination of the student comment examples evidences a willingness by Chilean students to comment in more depth about the nature and value of their experience, whereas South African and Australian students' comments were briefer and more to the

${ }^{117}$ Personal knowledge of second author. 
point, mainly focussing on their appreciation for increased practical skills development and greater understanding of the demands of legal practice.

Overall, it was noteworthy that none of the students reported a lack of increase or a decrease in any of the measured skills; however, it must be acknowledged that the survey had certain limitations. Firstly, it could be argued that students may be inclined to report positively on their experience when requested to participate in a survey of this nature whilst ignoring any shortfalls. Secondly, the use of student numbers or names in order to collate the pre-and post- clinic surveys did not allow for anonymity, which may have produced a more accurate result. Thirdly, the students may have also learned some of these skills in other courses, for instance, at the University of KwaZulu-Natal, in addition to the CLE courses, all students have to attend two Professional Training courses, the second of which requires participation in a moot court as counsel for either appellant or respondent. ${ }^{118}$ Nevertheless, bearing these limitations in mind, the groups, without exception, showed overwhelmingly positive increases in the GEI listed in Table 1 (above).

\section{CONCLUSION}

Despite the disparities in economic and social environments of the three diverse jurisdictions discussed in this article, there are many common challenges faced by Australian, Chilean and South African law graduates emerging into the workplace. Increased expectations in the legal profession require students to seize work experience opportunities in order to be in contention for sought-after graduate positions. As previously noted by LexisNexis, advances in legal tech, automation and AI are likely to alter the work of a lawyer substantially in the future. ${ }^{119}$ It is therefore more important than ever for law graduates to

\footnotetext{
${ }^{118}$ University of KwaZulu-Natal College of Law and Management Studies, Handbook for 2020 (2020) 91-91.

${ }^{119}$ Amy Simpson, 'Remote Working and the Virtual Law Firm' (Future of Law, 11 March 2020)

$<$ https://www.lexisnexis.co.uk/blog/future-of-law/coronavirus-remote-working-and-the-virtual-law-firm>.
} 
hone the skills required for the profession and be as well-rounded to meet future challenges. Law clinics provide them with the opportunity to experience the real challenges faced in practice, thereby developing 'soft' skills such as communication skills, empathy and resilience.

Recent employment setbacks precipitated by the COVID-19 pandemic may reverberate well into the future, and it has been predicted that the legal job market is likely to contract along with other industries. ${ }^{120}$ Studies have found that law graduates who entered the legal market during the Great Recession reported more difficulty finding jobs and less career satisfaction than earlier or later peers, ${ }^{121}$ and current law students may find themselves facing similar challenges.

Additionally, each of the three regions may face additional challenges, whether they be economic, social or political. The silver lining for law graduates, and a constant in the turmoil, is the ongoing need for lawyers and legal services. Significantly, in each of the jurisdictions discussed here there exists an established practice and support of clinical opportunities for law students. The results of the comparative survey together with the qualitative findings indicate that students on all three continents: Australia, South America and Africa, are reaping equivalent benefits from their clinical experience in preparing for the workplace. Now, more than ever, it is critical to present law students with as much practicebased experience as possible in a controlled clinical environment, irrespective of where they plan to practice law.

\footnotetext{
${ }^{120}$ Gabriel Kuris, ‘The Impact of the Coronavirus on Legal Education' US News (online, 23 March 2020) $<$ https://www.usnews.com/education/blogs/law-admissions-lowdown/articles/the-impact-of-the-coronavirus-onlegal-education>.

${ }^{121}$ ibid.
} 


\section{Acknowledgements}

The authors acknowledge the important contributions of Ms Janine Hicks and Dr Dave Holness, Clinicians and Lecturers at University of Kwazulu-Natal, South Africa in the collection and management of data in this project, as well as the invaluable research assistance provided by Ms Kana Nakano, Sessional Teaching Fellow at Bond University, in assisting with data management and background research, to bring this paper to fruition.

\section{Disclosure Statement}

No potential conflict of interest. 